\title{
Glaciotectonic deformation associated with the Orient Point-Fishers Island moraine, westernmost Block Island Sound: further evidence of readvance of the Laurentide ice sheet
}

\author{
Lawrence J. Poppe • Robert N. Oldale • \\ David S. Foster • Shepard M. Smith
}

Received: 28 November 2011 / Accepted: 8 June 2012 /Published online: 29 June 2012

(C) Springer-Verlag (outside the USA) 2012

\begin{abstract}
High-resolution seismic-reflection profiles collected across pro-glacial outwash deposits adjacent to the circa $18 \mathrm{ka}$ B.P. Orient Point-Fishers Island end moraine segment in westernmost Block Island Sound reveal extensive deformation. A rhythmic seismic facies indicates the host outwash deposits are composed of fine-grained glaciolacustrine sediments. The deformation is variably brittle and ductile, but predominantly compressive in nature. Brittle deformation includes reverse faults and thrust faults that strike parallel to the moraine, and thrust sheets that extend from beneath the moraine. Ductile deformation includes folded sediments that overlie undisturbed deposits, showing that they are not drape features. Other seismic evidence for compression along the ice front consists of undisturbed glaciolacustrine strata that dip back toward and underneath the moraine, and angular unconformities on the sea floor where deformed sediments extend above the surrounding undisturbed correlative strata. Together, these ice-marginal glaciotectonic features indicate that the Orient Point-Fishers Island moraine marks a significant readvance of the Laurentide ice sheet, consistent with existing
\end{abstract}

\footnotetext{
L. J. Poppe $(\bowtie) \cdot$ D. S. Foster

Coastal and Marine Geology Program, U.S. Geological Survey, Woods Hole, MA 02543, USA

e-mail: 1poppe@usgs.gov

R. N. Oldale

Emeritus, U.S. Geological Survey,

Oceanview Avenue,

North Falmouth, MA 02556, USA

S. M. Smith

Office of the Assistant Secretary for Environmental Observation and Prediction, National Oceanic Atmospheric Administration, Washington, DC 20230, USA
}

knowledge for neighboring coeval moraines, and not simply a stillstand as previously reported.

\section{Introduction}

Late Wisconsinan end moraines of the Laurentide ice sheet are prominent physiographic features across southern New England and Long Island, New York (Fig. 1). They form discontinuous ridges of stratified and unstratified glacial drift and, in places, coastal-plain deposits capped predominantly by till. The moraines stretch for tens of kilometers, comprise much of the coastal islands (Sirkin 1982), and are exposed as boulder lag deposits on the intervening sea floor (Schlee and Pratt 1970). Although there is general agreement that the southernmost late Wisconsinan moraine was formed geotectonically (Woodworth and Wigglesworth 1934; Kaye 1964; Oldale and O'Hara 1984), there is some debate on the mode of formation for the coastal recessional moraines. Some authors interpret them to be products of stagnation-zone retreat, whereby the position of the ice-sheet margin remained constant long enough for the drift to accumulate in a 'conveyor-belt' fashion (Schafer and Hartshorn 1965; Black 1982; Robinson et al. 2003). In this mode, supraglacial drift collected on the ice margin and was concentrated as underlying ice melted. Alternately, the recessional moraines of southern New England could be of glaciotectonic origin (Mills and Wells 1974; Oldale and O'Hara 1984; Boothroyd 2001). In this mode, older proglacial drift deposited during earlier stagnation-zone retreat would be thrust upward to form the cores of end moraines during ice-front readvance.

The purpose of this paper is to describe the facies and internal structures of pro-glacial deposits associated with the 


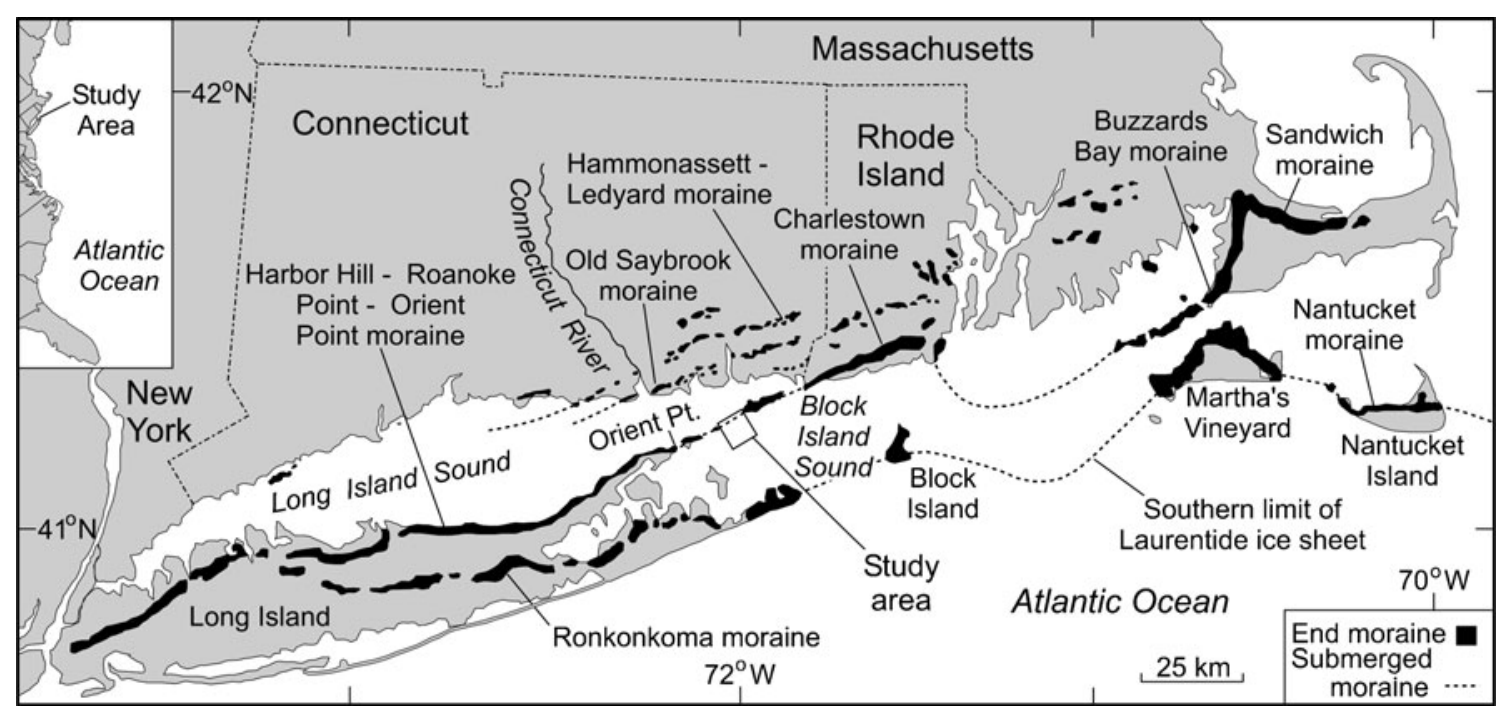

Fig. 1 Map showing the location of the study area, the major onshore moraines and their interpreted offshore extensions (Gustavson and Boothroyd 1987; Stone et al. 2005), and the southern limit of the Laurentide ice sheet at the last glacial maximum (23-24 ka B.P.)

Orient Point-Fishers Island moraine, to interpret the modes of formation for these internal structures, and to discuss the implications for ice-front dynamics during this time.

\section{Physical setting}

The youngest glacial drift on Long Island, New York, and in southeastern Connecticut is a product of late Wisconsinan advance of the Laurentide ice sheet (Sirkin 1982). Two late Wisconsinan end-moraine lines cross Long Island (Schafer and Hartshorn 1965; Sirkin 1982; Stone and Borns 1986). The Ronkonkoma moraine, which likely marks the maximum extent of late Wisconsinan glaciation between 23-24 ka B.P. (Balco et al. 2002), lies across central and southeastern Long Island, and extends eastward across Block Island, Martha's Vineyard, Nantucket, and the continental shelf (Fig. 1). To the north, the Harbor Hill-Roanoke Point-Orient Point moraine caps northern Long Island and continues across Fishers Island, New York. This recessional moraine, of which the Orient Point-Fishers Island moraine is a segment, was formed between 17.9-18.8 ka B.P. (Boothroyd 2001; Oldale 2001; Balco et al. 2002), and extends eastward where it is roughly the same age as the Charlestown moraine in Rhode Island, and the Buzzards Bay and Sandwich moraines in southeastern Massachusetts. This age range has been correlated with an inferred cold episode recorded in Greenland ice cores and a coeval ice-rafting event, suggesting that this part of the ice sheet was coupled to North Atlantic climate (Boothroyd 2001; Balco et al. 2002).

In addition to the two major moraine belts described above, several less prominent recessional moraines lie between the moraines on eastern Long Island and to the north of the study area in southeastern Connecticut, and several of these have been mapped and described as double linear belts (Sirkin 1982; Stone et al. 2005). Also, an unknown number of preWisconsinan glaciations can be inferred from isolated drift deposits and drilling data (Hartshorn 1976). However, none of these deposits has been recognized in or near the study area.

As the ice sheet retreated, meltwater was dammed behind the moraines, and pro-glacial lakes formed in the areas presently occupied by Block Island Sound (Bertoni et al. 1977; Needell and Lewis 1984) and Long Island Sound (Lewis and Needell 1987). Deltas prograded into the lakes, and thick deposits of fine-grained glaciolacustrine sediments accumulated on the lake bottoms during this time period (Lewis and DiGiacomo-Cohen 2000). The depression cut into the Orient Point-Fishers Island moraine that now forms the eastern entrance to Long Island Sound, referred to as the Race (Fig. 2), has been inferred to be the spillway for glacial Lake Connecticut (Stone et al. 2005). A consistent, late WisconsinanHolocene sequence of fluvial erosion (associated with the draining of the glacial lakes that occupied Long Island and Block Island sounds), followed by a marine transgression and a subsequent transition to present-day conditions, has been proposed for the marine areas surrounding the Race (Needell and Lewis 1984; Lewis and DiGiacomo-Cohen 2000).

Circulation within eastern Long Island Sound and western Block Island Sound is tidally dominated. It is weaker in broader, deeper areas and stronger in constricted areas such as the Race, where a large volume of water passes through a relatively narrow opening (Signell et al. 2000). There, strong tidal currents exceeding $2.5 \mathrm{~m} / \mathrm{s}$ (White and White 2010) have eroded and redistributed much of the glacial and younger sediment, producing large scour depressions that in places now exceed $100 \mathrm{~m}$ in depth (Poppe et al. 2006), and 


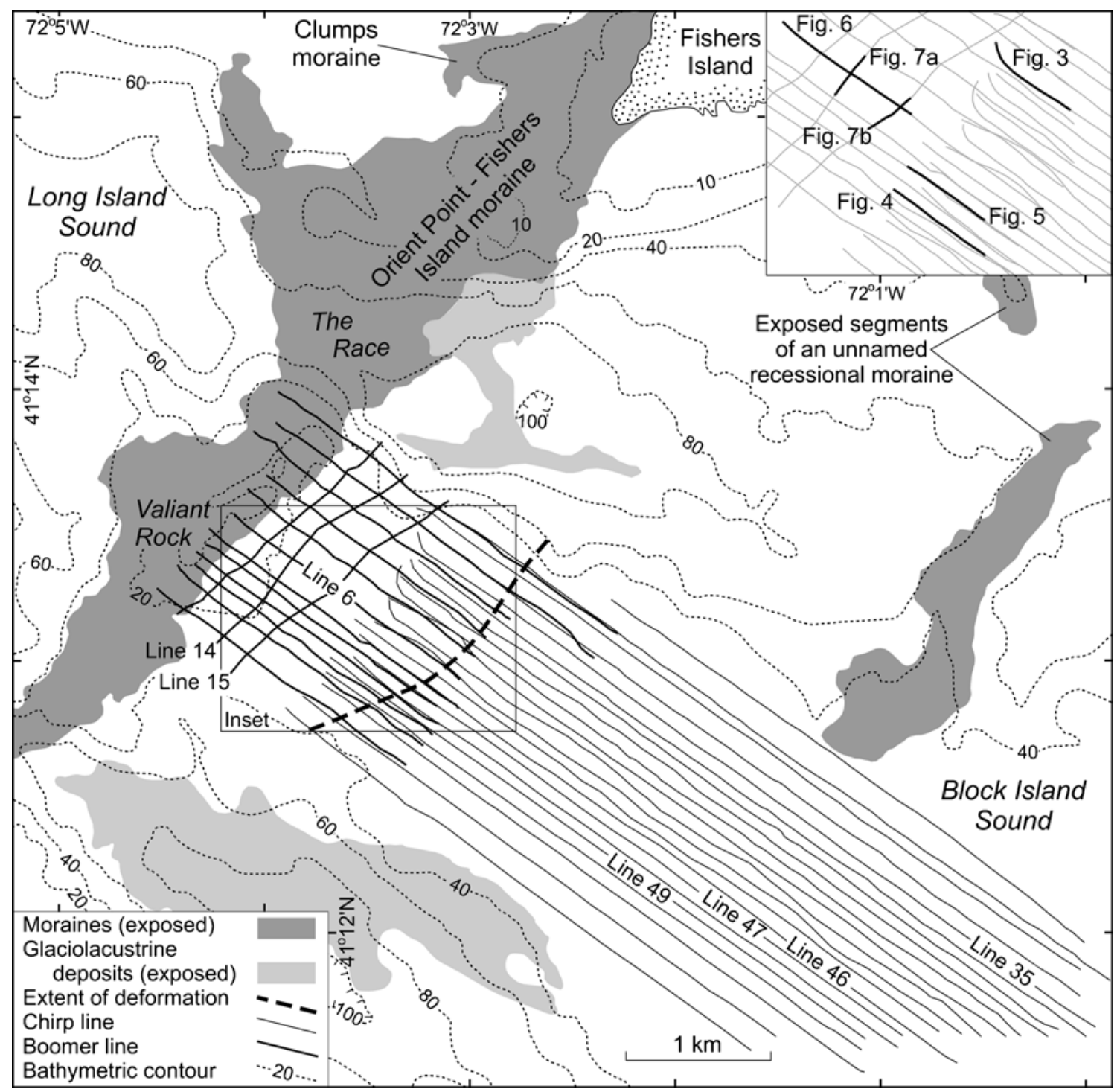

Fig. 2 Map of the study area showing tracklines of the chirp and boomer seismic-reflection profiles collected aboard the NOAA ship Thomas Jefferson and the USGS RV Rafael in the vicinity of the Orient PointFishers Island moraine, the exposed parts of the Clumps moraine and another minor recessional moraine, exposed glaciolacustrine deposits, scour depressions, the ice-distal extent of glaciotectonic deformation, as well as the locations of chirp lines $35,46,47$, and 49, boomer lines 6,14 , and 15, and of seismic-profile segments reported in Figs. 3, 4, 5, 6, and 7. Bathymetric contours are in meters

cruises. The first cruise, conducted aboard the NOAA ship Thomas Jefferson during October 2003, used a dualfrequency Knudsen 320BR 2-7 kHz chirp echosounder system with hull-mounted transducers, acquiring data along 21 lines totaling approximately $99 \mathrm{~km}$ (Fig. 2). A second cruise, conducted aboard the USGS research vessel Rafael during April 2010, collected boomer data along 15 lines totaling approximately $31 \mathrm{~km}$ in length with a GeoAcoustics Boomer source, GeoAcoustics power supply, Benthos AQ4 single-channel streamer, and Chesapeake Systems SonarWiz acquisition software. The boomer was fired at a rate of $0.5 \mathrm{~s}$ with a power output of $175 \mathrm{~J}$. The received signal was filtered between 100 and $3,000 \mathrm{~Hz}$ with a GeoPulse

data were collected adjacent to the moraine during two 
receiver. The data were recorded for $200 \mathrm{~ms}$ with a sample rate of $0.05 \mathrm{~ms}$ in standard SEG-Y format.

The raw boomer SEG-Y data were processed with SIOSEIS (2007) software. A bandpass filter was applied with a low cut of $800 \mathrm{~Hz}$ and a high cut of $200 \mathrm{~Hz}$, together with an automatic gain control (AGC) of $20 \mathrm{~ms}$ window length. The processed data were written to a new SEG-Y file, and Seismic Unix (Stockwell and Cohen 2007) was used to read the processed SEG-Y files and extract shot number, horizontal position, year, day, and time of day from the trace headers. Shot-point navigation data were converted to point and line shapefiles in ArcCatalog, which were used to georeference PNG images of the sesmic profiles created with Seismic Unix. Additionally, analog boomer data from two previous State of Connecticut/USGS seismic cruises (Needell and Lewis 1984; Lewis and Needell 1987) aided in the geologic interpretation. Depth scales of the profiles shown in this paper assume a seismic velocity of $1,500 \mathrm{~m} / \mathrm{s}$.

\section{Results}

The high-resolution seismic-reflection data reveal distinctive patterns and features that can be correlated with geologic deposits and processes. The main stratigraphic units and their internal structures are described below.

\section{Stratigraphic units}

Acoustic basement is formed by a hard, irregular reflector that underlies most of the study area. Because the upper surface of this unit correlates with that of the unnamed recessional moraine that extends under the southeastern part of the study area (Fig. 2), it is inferred that these strata are composed primarily of undifferentiated glacial drift, rather than bedrock.

Most of the section in front (i.e., southeast) of the Orient Point-Fishers Island moraine is composed of a seismic facies characterized by finely laminated, rhythmic, parallel internal reflectors. These reflectors are in places relatively flat-lying; elsewhere, they drape the structural relief of the underlying undifferentiated drift (Figs. 3, 4 and 5), but also extend under the ice-distal edge of the Orient Point-Fishers Island moraine (Fig. 6). This facies exceeds $70 \mathrm{~m}$ in thickness, but thins toward the crest of the buried recessional moraine under the southeastern part of the study area, and is exposed within the scour depressions where it crops out along the walls and immediately adjacent to the moraine (Fig. 2). The largest exposure occurs along the northern wall of the scour depression southeast of Valiant Rock. There, a 'stepped-ledge' morphology and angular slump blocks visible in multibeam bathymetry data demonstrate a dense, cohesive nature suggestive of semi-consolidated fine-grained sediments (Poppe et al.
2006). Based on their seismic character, cohesive nature, and samples from coring studies (Bertoni et al. 1977; Needell and Lewis 1984), these deposits are interpreted to be varved glaciolacustrine sediments composed of clayey silt that record deposition in a low-energy, ice-distal, pro-glacial lake that was present in Block Island Sound during the late Wisconsinan.

The Orient Point-Fishers Island moraine overlies the glaciolacustrine deposits, forming an elongate northeast-trending bathymetric high along the northwestern edge of the study area. This bathymetric high extends to and correlates with the moraines on Fishers Island and Orient Point. Although highly variable, the average width of the moraine is about $0.8 \mathrm{~km}$, the average relief about $15 \mathrm{~m}$ and, where penetrated by the seismic signal, most internal reflectors are discontinuous and chaotic. Elsewhere, the glaciolacustrine deposits are overlain by a thin Holocene sand sheet. The sand, presumably reworked from the glacial and surrounding post-glacial deposits, thickens seaward of the buried recessional moraine where tidal-current speed decreases (White and White 2010). The chirp seismic signal is attenuated as the sand sheet progressively thickens, preventing penetration to the stratified drift in the extreme southeastern part of the study area.

\section{Glaciotectonic deformation}

Deformation structures related to unit shortening are widespread, pervasive, and well preserved in the glaciolacustrine deposits adjacent to and beneath the Orient Point-Fishers Island moraine (Figs. 4, 5, 6 and 7). Maximum width of the band containing these structures exceeds $1.65 \mathrm{~km}$ near the center of these deposits, but narrows along the northeastern and southwestern edges, plausibly explained by Holocene marine erosion that has removed the upper part of the section (Figs. 2 and 3). Deformation structures within the band increase in average size, frequency, and depth within the sediments with decreasing distance to the moraine. For example, depth of disturbance never exceeds $21 \mathrm{~m}$ near the distal extent, but deformation structures near the moraine extend over $34 \mathrm{~m}$ into the sediment. The deformation is variably brittle and ductile, but predominantly compressive in nature. Tensional structures are absent.

Brittle deformation includes thrust faults, oblique-slip faults, strike-slip faults, and thrust sheets. The thrust faults farthest from the moraine are typically listric in character, having fault planes that curve and become shallower in dip with depth (Figs. 4 and 5). These faults have strikes that parallel the trend of the moraine, shallow dips that average less than $17^{\circ}$, vertical offsets ranging from 1.5 to $7.5 \mathrm{~m}$, and blocks with maximum widths of less than $245 \mathrm{~m}$. Thrust faults closer to the moraine are similar in orientation, but they are more numerous and have flat fault planes (Fig. 6). These faults have steeper dips (19-44 ${ }^{\circ}$ ), and greater vertical offsets that in places exceed $13 \mathrm{~m}$. In cross section, the thrust blocks have a 
Fig. 3 High-resolution seismicreflection profile and interpretation for chirp line 35 , with evidence of undisturbed stratified drift in front of the Orient Point-Fishers Island moraine, characterized by finely laminated, rhythmic, parallel internal reflectors, and of erosion in the NW sector

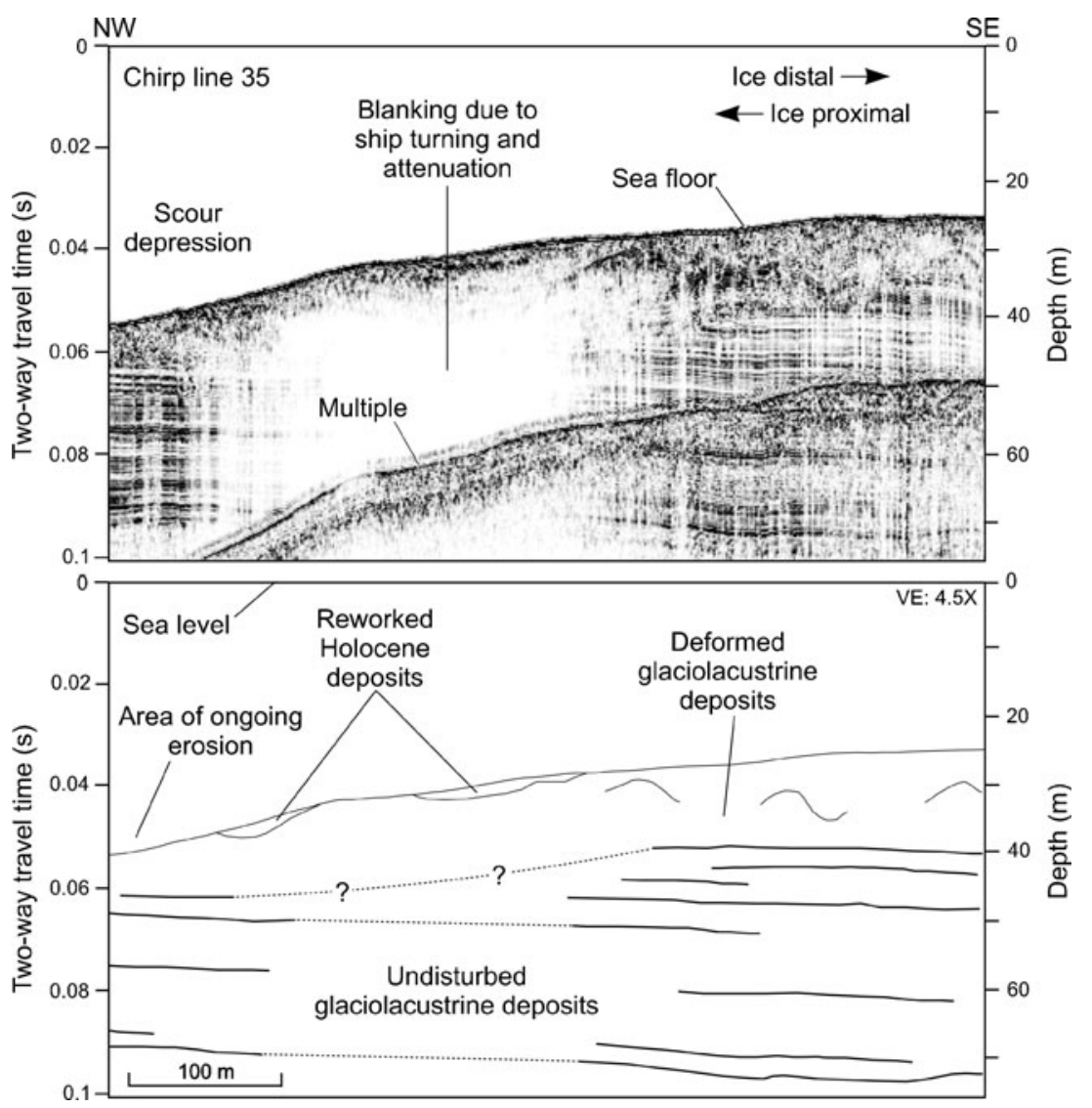

faults (Fig. 7a). In places where these faults reach the sea floor (Figs. 4 and 5), hanging wall blocks have been shifted as much as $9 \mathrm{~m}$ above the surrounding seabed, forming ice-thrust 'bell-shaped' architecture in that they are thicker near the middle and taper laterally toward their edges, where they variably pinch out or terminate in strike-slip and oblique-slip

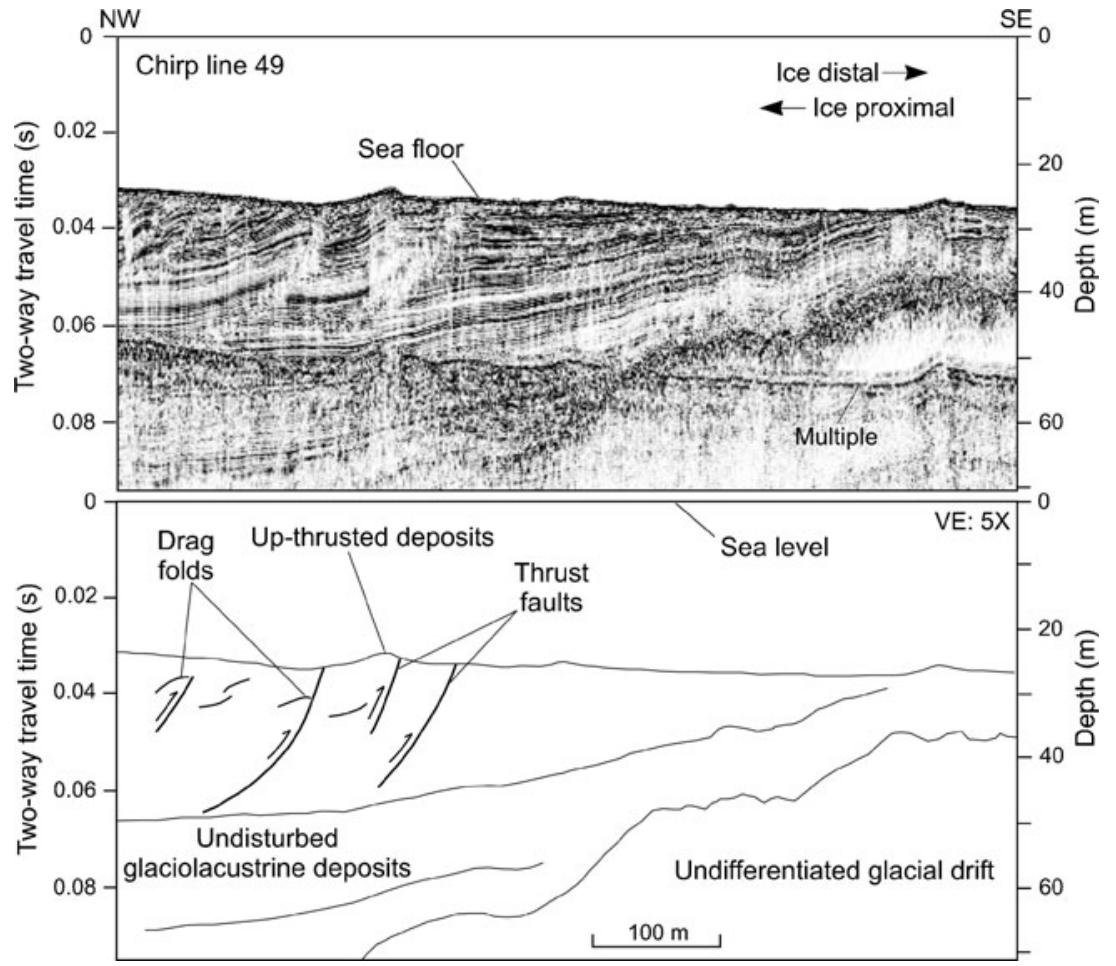

Fig. 4 High-resolution seismicreflection profile and interpretation for chirp line 49 , with evidence of thrust faults and drag folds in the glaciotectonically disturbed stratified drift 
Fig. 5 High-resolution seismic-reflection profile and interpretation for chirp line 47 , with evidence of brittle (thrust faults) and ductile (drag, synclinal, and anticlinal folds) deformation in the glaciotectonically disturbed stratified drift

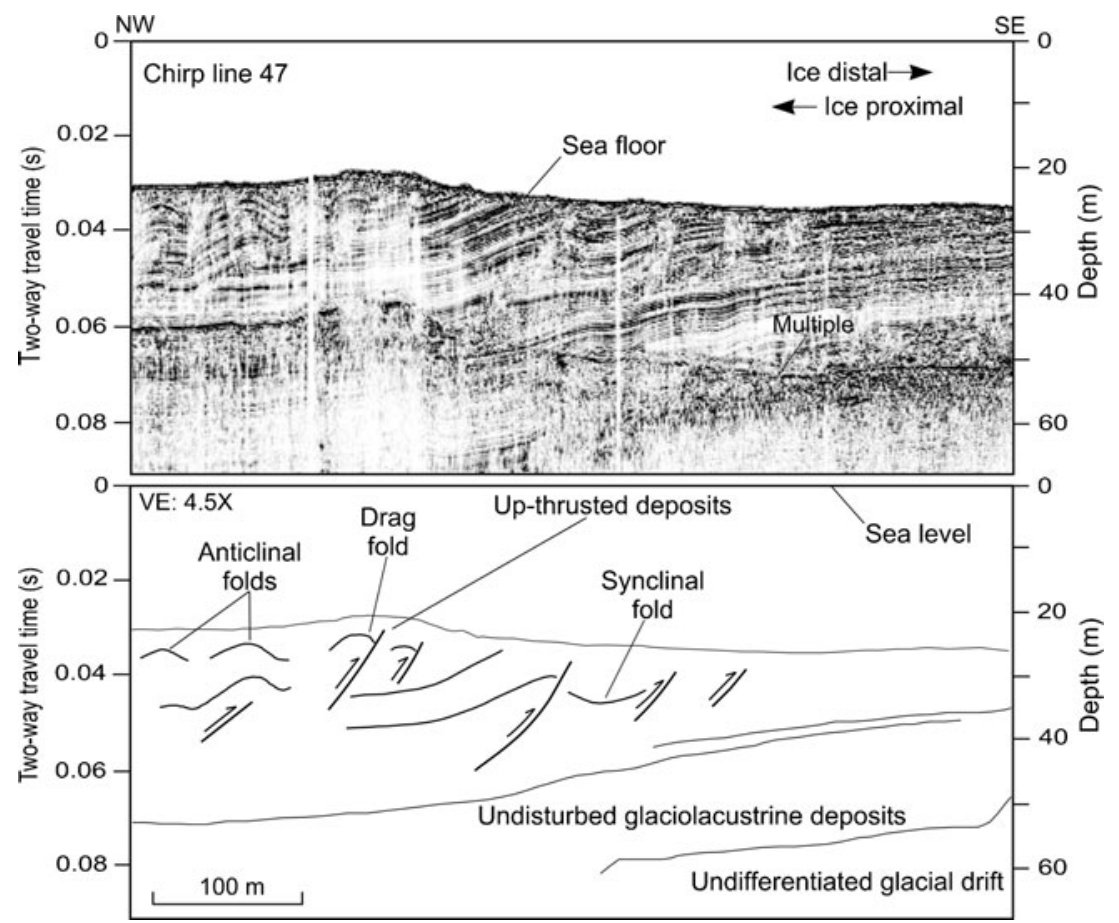

ridges with pronounced bathymetric expression (Poppe et al. 2006). Although permafrost could have strengthened the semi-consolidated mud and enabled it to be thrust as rigid sheets, the cohesive nature of glaciolacustrine deposits suggests that this may not have been essential to the formation of brittle deformation structures at this location along the ice margin.
Some seismic profiles collected normal to the moraine trend reveal intervals characterized by smaller, tilted, and buckled fault blocks that are in places bordered by faults with little or no vertical displacement (Fig. 6). Blocks in these intervals tilt both toward and away from the moraine, giving the intervals a 'jumbled' appearance. When viewed in cross section, however, the blocks are bounded laterally

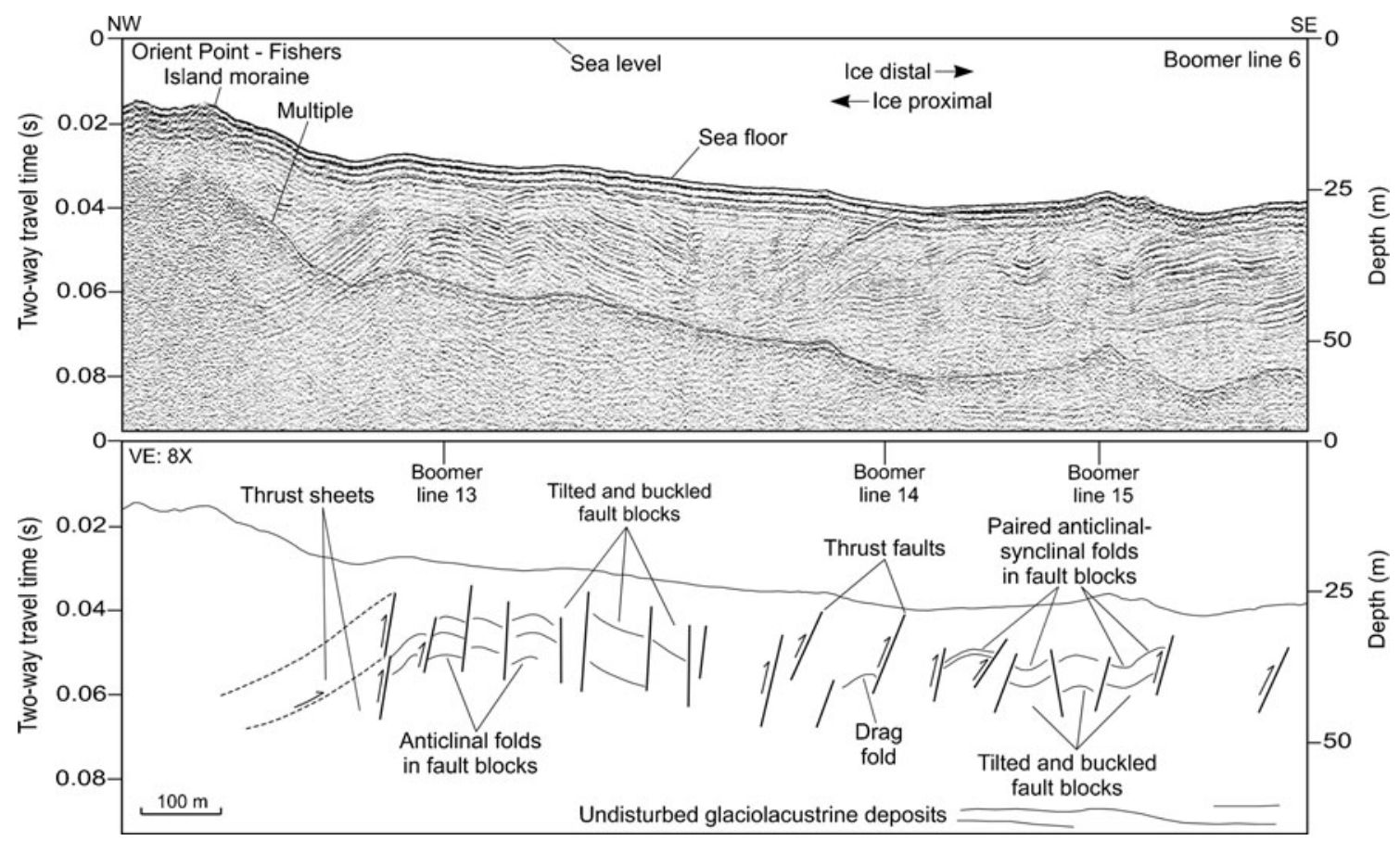

Fig. 6 High-resolution seismic-reflection profile and interpretation for boomer line 6, showing thrust sheets extending from beneath the Orient Point-Fishers Island moraine, thrust faults, zones of buckled and tilted blocks, and the locations of boomer tie lines 14 and 15 reported in Fig. 7 

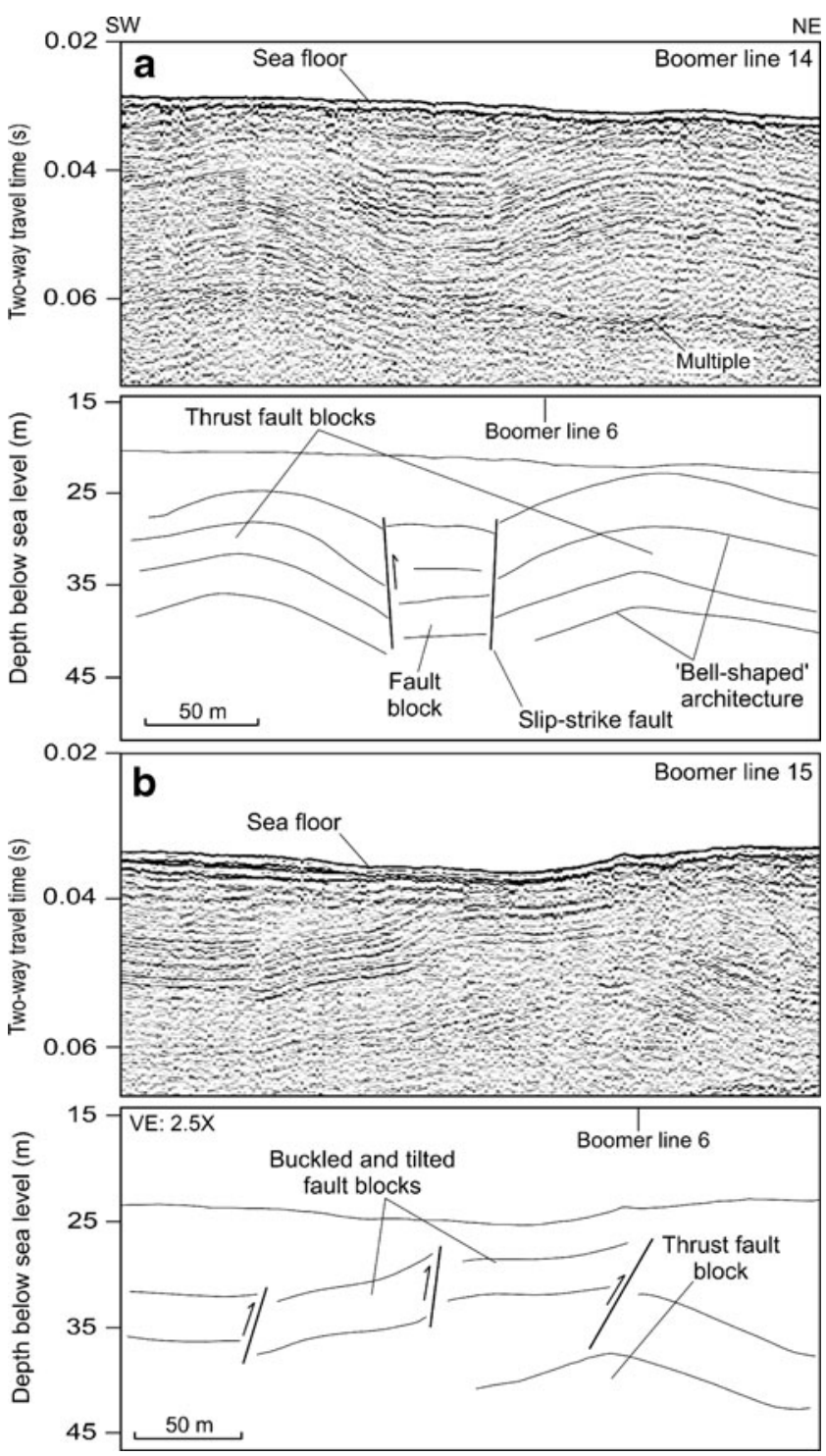

Fig. 7 High-resolution seismic-reflection profiles and interpretations for boomer tie lines 14 and 15. a Thrust faults are 'bell-shaped' in cross section, taper toward their lateral extent, and terminate in faults or pinch outs. b Shear zones of buckled and tilted fault blocks in cross section are compressive in nature

by thrust faults and situated between adjacent southeasttrending thrust fault blocks (Fig. 7a, b). Apparently, emplacement and, perhaps, subsequent gravitational settling from asymmetric loading of the southeast-trending thrust fault blocks has sheared and compressed the intervening deposits. In any case, the blocks in these intervals are not slump or collapse structures created under tensional conditions.

Thrust sheets of glaciolacustrine sediments that were presumably forced upward and outward from beneath the moraine by the advance and weight of the overriding ice can be identified in the boomer data (Fig. 6), and the orientation and dip of these features are similar to those of the smallerscale, more ice-distal thrust faults. These sheets, which have been stacked one on top of another, can individually exceed $20 \mathrm{~m}$ in thickness. Stacking of the sheets has resulted in vertical and horizontal displacements that exceed 35 and 190 m, respectively.

Ductile deformation features, which have amplitudes that in places exceed $5 \mathrm{~m}$, are conspicuous because the features are enhanced and made more recognizable by the rhythmic seismic signature of the glaciolacustrine deposits. These features commonly occur in close association with the faulting described above and include anticlines, synclines, drag folds, and a recumbent fold. Anticlines occur both individually and paired with synclines, and not always in conjunction with faulting. Where associated with faulting, fractures are typically observed at the transition from anticline to syncline and, because unlithified sediments tend to bend before they break, it is likely that the folding occurred prior to the faulting. Synclines unpaired with anticlines are absent. Small drag folds occur within strata along the hanging walls of some thrust faults, accentuating the upward movement (Figs. 4 and 5). A recumbent fold, observed on chirp line 46 (Fig. 2), is overturned toward the southeast (data not shown). Except in the intervals of buckled, tilted blocks compressed between adjacent thrust faults (Fig. 7b), fold axes strike northeast, paralleling the trend of the moraine and strikes of the thrust faults. Although the bedding of glaciolacustrine deposits would conform to the underlying topography, the presence of these folded sediments over flat-lying, undisturbed deposits is evidence that they are not simply drape features.

\section{Discussion}

Textural and morphological characteristics of the stratified glacial drift in front of the Orient Point-Fishers Island end moraine segment and the glaciotectonic deformation structures present within these deposits provide evidence that the moraine was formed during a significant glacial readvance of the Connecticut-Central Rhode Island lobe, and is not the result of deposition along a stalled ice front.

Pro-glacial drift

Evidence for ice-sheet readvance provided by the composition and character of the pro-glacial stratified drift within the study area includes four main aspects.

Aspect 1: the outwash is cohesive, muddy, and has a spatially uniform rhythmic seismic signature (Poppe et al. 2006), these being attributes typical of sediments deposited by gravitational settling in low-energy, ice-distal glaciolacustrine sedimentary environments (Teller 1987; Golledge and Phillips 2008). Because a stalled ice-front position would be much more likely to have high-energy ice-proximal sedimentary environments and to produce spatially discontinuous, 
coarse-grained, fluvial outwash (Flint 1971; Bloom 1991; Bennett et al. 2000), the thickness and close proximity of fine-grained glaciolacustrine strata to the moraine suggests that these deposits pre-date those of the moraine, and that the readvance that caused this juxtaposition of incongruent deposits extended at least several kilometers. Although not well constrained by the present data, ice-front readvance of the Harbor Hill moraine has been estimated to be at least several tens of miles to the south (Mills and Wells 1974), and readvance of the Buzzards Bay and Sandwich moraines has been estimated to be as much as $25 \mathrm{~km}$ (Oldale and O'Hara 1984).

Aspect 2: sediment-laden meltwaters from a stalled icefront position would be expected to rapidly build deltas and outwash plains that prograde from the moraine, producing foreset and bottomset beds that should dip toward the southeast (Kupsch 1962; Uchupi et al. 1996). However, the undisturbed pro-glacial stratified drift within the study area is either flat-lying or dips gently northwest toward the moraine (Figs. 3, 4,5 and 6), suggesting that the moraine in its present position was not the source.

Aspect 3: the deformed glaciolacustrine strata are underlain by similar, but relatively flat-lying beds that show no deformation. This indicates that departures from the horizontal in the upper part of the section are not simply drape features over underlying topography (Kupsch 1962; Oldale and O'Hara 1984).

Aspect 4: relatively flat-lying reflectors in the seismicreflection profiles here interpreted to be undisturbed late Wisconsinan glaciolacustrine strata extend under the icedistal edge of the moraine. The presence of the moraine over these strata can be explained only by glacial readvance over the pre-existent drift.

\section{Deformation structures}

Evidence for readvance of the ice sheet is provided by the type, orientation, and distribution of deformation structures in the glaciolacustrine deposits. This evidence includes seven key aspects.

Aspect 1: numerous thrust faults with strikes roughly parallel that of the moraine, trending southwest to northeast. This orientation indicates that compression was perpendicular to the advancing ice front (Kupsch 1962; Mills and Wells 1974; Hicock and Dreimanis 1985; Larsen et al. 2003), and that displacement toward the southeast was induced by ice movement from the northwest. This conclusion correlates with the interpreted direction of ice movement shown by glacially carved lineations on bedrock exposures to the northwest beneath Long Island Sound (Poppe et al. 2006).

Aspect 2: regardless of distance from the Orient PointFishers Island moraine, faults that intersect the sea floor commonly affect the benthic topography. Displaced strata on the hanging walls have positive relief in relation to adjacent coeval drift surfaces, suggestive of thrusting and overthrusting (Oldale and O'Hara 1984; Aber and Ruszczynska-Szenajch 1997).

Aspect 3: large-scale dislocations of strata in the form of thrust sheets beneath the ice-distal part of the moraine are conspicuous in the 2010 boomer data (Fig. 6). These sheets provide evidence that the moraine was formed by the thrusting and stacking of pro-glacial drift (Oldale and O'Hara 1984; Hart and Boulton 1991; Roberts et al. 2009). Although older thrust sheets are probably present further under the moraine, they are not visible in the seismic profiles, owing to the boulder lag that caps the moraine and creates a highly reflective acoustic surface (Poppe et al. 2006), and presumably also to erosion and disruption by the overriding ice.

Aspect 4: folding is widespread and closely associated with the faulting (Figs. 4, 5 and 6). Anticlines and synclines are common, recumbent folds are present, and drag folds occur along the thrust faults. Because the orientation of the fold axes and strikes of the thrust fault planes are similar (Larsen et al. 2003), it is here contended that the ductile deformation was also caused by an ice front readvancing from the northwest.

Aspect 5: both faulting and folding progressively decrease in magnitude and frequency with distance toward the southeast from the Orient Point-Fishers Island moraine. The deformation disappears completely before the crest of the buried minor recessional moraine, and slightly seaward where the southeastward-thickening sand sheet attenuates the chirp seismic signal and obscures the underlying units. If the deformation was not related to emplacement of the moraine, or if the ice front was subject to regular minor fluctuations in position, then the distribution of these structures would be much more random.

Aspect 6: normal faults, grabens, collapse structures related to the melting of buried ice, and other features typical of tensional deformation (Flint 1971; Bennett et al. 2000; Weaver and Arnaud 2011) are absent or unidentifiable in the seismic-reflection data. Although strike-slip and obliqueslip faults are present, they are restricted to shear zones at the edges of or between adjacent thrust faults. Distortion within these zones is extreme, as shown by tilted strata that have dip directions different from that of the regional dip, but ductile deformation within the fault blocks and thrust faults bordering the blocks reveal compression (Figs. 6 and $7 b$ ). If the pro-glacial deformation adjacent to the moraine was caused by frequent small-scale advances and retreats prior to establishment of a stalled ice-front position at the present location of the moraine, then tensional structures should also be a component of the deformation.

Aspect 7: New England is considered to be tectonically inactive and regionally of low seismicity. Although fault lines cross New England, there is no obvious relationship 
between the minor earthquakes that do sporadically occur and the geologically mapped faults (Ebel and Kafka 1991). Therefore, compressive deformation of glacial drift in terms of the scale, orientation, and distribution observed within the study area is almost certainly of glaciotectonic origin.

The Orient Point-Fishers Island end moraine segment is part of a prominent recessional ice-margin position that extended from Harbor Hill on western Long Island, New York through the northern shore of Cape Cod, Massachusetts. Earlier work onshore along the Harbor Hill-Roanoke PointOrient Point moraine on Long Island (Mills and Wells 1974; Sirkin 1982) and along the Buzzards Bay and Sandwich moraines on the Elizabeth Islands and Cape Cod (Oldale and O'Hara 1984) reported drift deposits that were variably intercalated, folded, and thrust-faulted. Those findings, and sediment-mass calculations of the Charlestown moraine (Boothroyd 2001), led those authors to conclude that the moraines were entirely, or at least in part, of glaciotectonic origin. The seismic profiles and interpretations of the present study support their findings by providing detailed information on the character and distribution of compressive deformation features in pro-glacial drift, indicating that the Orient PointFishers Island moraine is also a product of glacial readvance, and not the result of a stalled ice-front position as previously maintained by Schafer and Hartshorn (1965) and Black (1982). Because similar dynamics have now been reported for all of the moraines along the circa $18 \mathrm{ka}$ B.P. Laurentide icemargin position, and because this age correlates well with a widespread cooling cycle, it is contended that the application of a regional surge model would be appropriate for the moraines of southern New England formed during this time period.

\section{Conclusions}

This paper documents ice-thrust deformation associated with the Orient Point-Fishers Island moraine, providing the first marine evidence of late Wisconsinan ice-front readvance in this region. Seismic profiles collected across proglacial outwash deposits adjacent to the moraine reveal a late Wisonsinan section composed largely of fine-grained glaciolacustrine deposits that contain numerous brittle and ductile deformation features. Brittle features include thrust sheets and thrust, reverse, strike-slip, and oblique-slip faults. Ductile features include anticlines, synclines, recumbent folds, and drag folds. The lithology and thickness of the glaciolacustrine strata, as well as their close proximity to and extension beneath the moraine demonstrate that these deposits pre-date those of the moraine. The type, orientation, and distribution of the deformation features indicate a glaciotectonic origin. Based on evidence provided by the pro-glacial drift and deformation features, it is suggested that the Orient Point-Fishers Island moraine formed during a significant readvance of the Laurentide ice sheet, rather than during a stillstand as previously reported.

Acknowledgements We would like to thank the officers and crew of the NOAA ship Thomas Jefferson for their help in collecting the chirp data. This work was supported by the Connecticut Department of Environmental Protection, and the Atlantic Hydrographic Branch of the National Oceanic and Atmospheric Administration. This manuscript has benefited from critical internal reviews by Dave Twichell and Bill Schwab (both USGS), and comments from N.R. Golledge.

\section{References}

Aber JS, Ruszczynska-Szenajch H (1997) Origin of Elblag Upland, northern Poland, and glaciotectonism in the southern Baltic region. Sed Geol 111:119-134

Balco G, Stone JOH, Porter SC, Caffee MW (2002) Cosmogenicnuclide ages for New England coastal moraines, Martha's Vineyard and Cape Cod, Massachusetts, USA. Quat Sci Rev $21: 2127-2135$

Bennett MR, Huddart D, McCormick T (2000) An integrated approach to the study of glaciolacustrine landforms and sediments: a case study from Hagavatn, Iceland. Quat Sci Rev 19:633-665

Bertoni R, Dowling JJ, Frankel L (1977) Fresh-water lake sediments beneath Block Island Sound. Geology 5:631-635

Black RF (1982) Modes of deglaciation of Connecticut: a review. In: Larson GJ, Stone BD (eds) Late Wisconsinan glaciation of New England. Kendall/Hunt, Dubuque, pp 35-60

Bloom AJ (1991) Geomorphology - a systematic analysis of late Cenozoic landforms. Prentice Hall, Englewood Cliffs

Boothroyd JC (2001) Late Pleistocene depositional environments and paleoclimate, Rhode Island. Geol Soc Am Abs Prog 33:14

Ebel JE, Kafka AL (1991) Earthquake activity in the northeastern United States. In: Slemmons DB, Engdahl ER, Zoback MD, Blackwell DD (eds) Neotectonics of North America. Decade of North American Geology, Geological Society of America, Boulder, CO, GSMV-1, chap 15, pp 277-290

Flint RL (1971) Glacial and Quaternary geology. Wiley, New York

Golledge NR, Phillips E (2008) Sedimentology and architecture of De Geer moraines in the western Scottish Highlands, and implications for grounding line glacier dynamics. Sed Geol 208:1-14

Gustavson TC, Boothroyd JC (1987) A depositional model for outwash, sediment sources, and hydrologic characteristics, Malaspina Glacier, Alaska: a modern analog of the southeastern margin of the Laurentide ice sheet. Geol Soc Am Bull 99:187200

Hart JK, Boulton GS (1991) The interrelation of glaciotectonic and glaciodepositional processes within the glacial environment. Quat Sci Rev 10:335-350

Hartshorn JH (1976) Quaternary problems in southern New England. In: Mahaney WC (ed) Quaternary stratigraphy of North America. Dowden, Hutchinson, and Ross, Stroudsburg, pp 91-92

Hicock SR, Dreimanis A (1985) Glaciotectonic structures as useful ice-movement indicators in glacial deposits: four Canadian case studies. Can J Earth Sci 22:339-346

Kaye CA (1964) Illinoian and early Wisconsin moraines of Martha's Vineyard, Massachusetts. US Geol Surv Prof Pap 501-C

Kupsch WO (1962) Ice-thrust ridges in western Canada. J Geol $70: 582-594$

Larsen GJ, Ehlers J, Gibbard PL (2003) Large-scale glaciotectonic deformation in the Great Lakes basin, USA-Canada. Boreas 32:370-385 
Lewis RS, DiGiacomo-Cohen ML (2000) A review of the geologic framework of the Long Island Sound basin with some observations relating to postglacial sedimentation. J Coastal Res 16:522532

Lewis RS, Needell SW (1987) Maps showing stratigraphic framework and Quaternary geologic history of eastern Long Island Sound. US Geological Survey Miscellaneous Field Studies Map MF-1939-A, scale 1:125,000

Mills HC, Wells PD (1974) Ice-shove deformation and glacial stratigraphy of Port Washington, Long Island, New York. Geol Soc Am Bull $85: 357-364$

Needell SW, Lewis RS (1984) Geology of Block Island Sound, Rhode Island and New York. US Geological Survey Miscellaneous Field Studies Map MF-1621, scale 1:125,000

Oldale RN (2001) Cape Cod and the islands, the geologic story. On Cape Publications, Yarmouth

Oldale RN, O'Hara CJ (1984) Glaciotectonic origin of the Massachusetts coastal end moraines and a fluctuating late Wisconsinan ice margin. Geol Soc Am Bull 95:61-74

Poppe LJ, DiGiacomo-Cohen ML, Smith SM, Stewart HF, Forfinski NA (2006) Seafloor character and sedimentary processes in eastern Long Island Sound and western Block Island Sound. Geo-Mar Lett 26:59-68. doi:10.1007/s00367-006-0016-4

Roberts DH, Yde JC, Knudsen NT, Long AJ, Lloyd JM (2009) Ice marginal dynamics during surge activity, Kuannersuit Glacier, Disko Island, West Greenland. Quat Sci Rev 28: 209-222

Robinson DS, Ford B, Herbster H, Waller JN (2003) Marine archeological assessment, Cape Wind Project, Nantucket Sound, Massachusetts. PAL Publications, Pawtucket, RI, PAL Rep no 1485, chap 3, pp 6-7

Schafer JP, Hartshorn JH (1965) The Quaternary of New England. In: Wright HE, Frey DG (eds) The Quaternary of the United States. Princeton University Press, Princeton, pp 113-128

Schlee J, Pratt RM (1970) Atlantic shelf and slope of the United States gravels of the northeastern part. US Geol Surv Prof Pap 529-H
Signell RP, List JH, Farris AS (2000) Bottom currents and sediment transport in Long Island Sound: a modeling study. J Coastal Res 16:551-566

SIOSEIS (2007) SIOSEIS - The introduction. SIOSEIS, http://sioseis. ucsd.edu/sioseis.html, accessed 12 October 2011

Sirkin LA (1982) Wisconsinan glaciation of Long Island, New York to Block Island, Rhode Island. In: Larson GJ, Stone BD (eds) Late Wisconsinan glaciation of New England. Kendall/Hunt, Dubuque, pp 35-60

Stockwell JW, Cohen JK (2007) The new SU user's manual (v. 3.3). Colorado School of Mines, Center for Wave Phenomena, Golden, $\mathrm{CO}$

Stone BD, Borns HW (1986) Pleistocene glacial and interglacial stratigraphy of New England, Long Island and adjacent Georges Bank and Gulf of Maine. In: Sibrava V, Bowen DQ, Richmond GM (eds) Quaternary glaciations in the northern hemisphere. Pergamon Press, Oxford, pp 39-52

Stone JR, Schafer JP, London EH, DiGiacomo-Cohen M, Lewis RS, Thompson WB (2005) Quaternary geologic map of Connecticut and Long Island Sound basin. US Geological Survey, Scientific Investigations Map 2784, 2 sheets, scale 1:125,000

Teller JD (1987) Proglacial lakes and the southern margin of the Laurentide ice sheet. In: Ruddiman WF (ed) North America and adjacent oceans during the last deglaciation. Geology of North America, K-3. Geological Society of America, Boulder, CO, pp 39-59

Uchupi E, Giese GS, Aubrey DG, Kim DJ (1996) The late Quaternary construction of Cape Cod, Massachusetts - a reconsideration of the W.M. Davis model. Geol Soc Am Spec Pap 309

Weaver L, Arnaud E (2011) Polyphase glacigenic deformation in the Waterloo moraine, Kitchner, Ontario, Canada. Sed Geol 235:292-303

White RE Jr, White LF (2010) Eldridge tide and pilot book. White Instruments, Medfield, pp 85-97

Woodworth JB, Wigglesworth E (1934) Geography and geology of the region including Cape Cod, the Elizabeth Islands, Martha's Vineyard, No Mans Land, and Block Island. Harvard College Museum of Comparative Zoology Memoir 52 